\title{
Pemanfaatan Limbah Sludge Kertas PT.Adiprima Suraprinta dalam Pembuatan Batako
}

\author{
A. Yusuf $Z^{1)}$, Estutie Maulanie ${ }^{2)}$, M. Singgih P. ${ }^{3)}$, Lukman ${ }^{4)}$ \\ 1,2,3)Staft Pengajar Diploma Teknik Sipil ITS \\ 4)Mahasiswa Diploma Teknik Sipil ITS
}

\begin{abstract}
ABSTRAK
Limbah padat sludge yang dihasilkan dari pengolahan kertas oleh PT. Adiprima Suraprinta dengan produksi limbah perharinya mencapai 71 truk/ hari atau setara dengan 350 ton/ hari yang terdiri dari 70\%air. Salah satu upaya untuk mengatasi limbah tersebut adalah dengan mendaur ulang limbah tersebut menjadi sesuatu yang berguna. limbah padat (sludge) pabrik kertas PT. Adiprima Suraprinta dapat dimanfaatkan dalam pembuatan bahan bangunan, salah satunya adalah batako. Memanfaatkan bahan limbah padat (sludge) PT. Adiprima Suraprinta menjadi material yang berguna dan menghasilkan campuran yang mempunyai kuat tekan paling tidak sama dengan Bata merah. Diharapkan mampu mengurangi kebutuhan pasir yang biasa dipakai pada umumnya, sehingga masyarakat umum dapat menikmati rumah layak tinggal dan aman serta nyaman. Pelaksanaan pekerjaan dimulai dari pengambilan bahan baku, pegujian material dan pembuatan benda uji mortar ukuran $5 \times 5 \times 5 \mathrm{~cm}^{3}$ dari beberapa variasi campuran dengan tujuan mencari komposisi yang optimal. Uji kuat tekan mortar dilakukan pada umur 7,14 dan 28 hari. Perawatan mortar dilakukan dengan cara disiram pakai air tawar. Penimbangan berat kering mortar, kemudian diaplikasikan pada elemen batako ukuran $20 \times 18 \times 10 \mathrm{~cm}^{3}$. Dari hasil evaluasi ternyata komposisi 6 yaitu 1semen: 3,75pasir:1,25sludge dari komposisi optimal dan ekonomis mempunyai kuat tekan benda uj i mortar umur 28 hari sebesar 25, 33 $\mathrm{kg} / \mathrm{cm}^{2}$ melampaui kuat tekan HB20 yaitu sebesar $20 \mathrm{~kg} / \mathrm{cm}^{2}$ yang digunakan untuk dinding rumah sederhana. Nilai resapan umur 28 dan 60 hari yaitu 7,9\% dan 8,0\% Komposisi 6 tersebut akan diaplikasikan pada benda uji batako hasilnya yaitu mempunyai kuat tekan umur 28 dan 60 hari sebesar 22,33kg/ $\mathrm{cm}^{2}$ dan $23,67 \mathrm{~kg} / \mathrm{cm}^{2}$ melampaui kuat tekan HB20 sebesar $20 \mathrm{~kg} / \mathrm{cm}^{2}$ yang mempunyai kegunaan untuk dinding rumah sederhana. Nilai resapannya umur 28 dan 60 hari berturut-turut sebesar 8,2\% dan 8,4\% yang berdasarkan SII.0285-1980 tidak ada syaratnya. Untuk berat kering mempunyai berat yang lebih ringan dibanding dengan berat batako dipasaran.
\end{abstract}

Kata kunci : Sludge, Batako

\section{PENDAHULUAN}

Pemanfaatan limbah padat pabrik kertas PT. Adiprima Suraprinta dapat digunakan sebagai bahan baku pembuatan bahan bangunan yaitu sebagai bahan baku alternatif pembuatan batako, pembuatan batako untuk rumah sederhana dengan campuran semen portland, pasir, dan sludge . Sludge yang dipakai pada penelitian ini adalah dalam keadaan kering , dikarenakan pada waktu penelitian yang menggunakan sludge basah sebagai bahan pengisi hasil kuat tekannya yang dihasilkan tidak optimal. Selain itu pada waktu pencampuran susah nyampurnya juga tidak homogen dan permukaannya kebanyakan kelihatan sludge basah sehingga tidak rata.
Secara garis besar dari upaya penelitian yang akan dilakukan, adalah

1. Mencari banyaknya sludge yang dapat disubstitusikan sebagai agregat dalam pembuatan batako sehingga menghasilkan kuat tekan yang sesuai dengan standart yang berlaku (SII.028580).

2. Apakah bahan limbah padat (sludge) dapat menjadi material yang berguna dan menghasilkan campuran yang mempunyai kuat tekan paling tidak sama dengan Bata merah

\section{TINJ AUAN PUSTAKA}

Batako adalah suatu jenis unsur bangunan berbentuk bata yang dibuat dari bahan 
utama semen Portland, agregat, dan air yang digunakan untuk pemasangan pagar dan pondasi. Batako memiliki ukuran $40 \mathrm{~cm} \times 18 \mathrm{~cm} \times 10 \mathrm{~cm}$ lebih besar dibandingkan batu bata yang ukurannya $20 \mathrm{~cm} \times 10 \mathrm{~cm} \times 15 \mathrm{~cm}$ sehingga batako merupakan tipe bahan bangunan yang bersifat ekonomis, cepat pemasangannya, menggunakan sedikit batako dari pada batu bata merah. Batako juga dapat meredam suara karena terdapat lubang-lubang. Pada umumnya batako tidak diplester dibandingkan dengan batu bata merah karena memiliki permukaan yang lebih rata, sehingga dapat langsung dicat. Pada penelitian yang dilakukan ini terdapat pemodelan batako dengan campuran sludge. Pemodelan bahan campuran dinding tersebut diharapkan menghasilkan kuat tekan sesuai syarat SII.0285-80.

\subsection{Material Penyusun Batako 2.1.1 Semen Portland (Pc)}

Semen merupakan bahan campuran yang secara kimiawi aktif setelah berhubungan dengan air.

Semen Portland adalah bahan konstruksi yang paling banyak digunakan dalam pekerjaan beton. Menurut ASTM C-150, 1985, semen portland didefinisikan sebagai semen hidrolis yang dihasilkan dengan cara menggiling klinker yang terdir dari kalsium silikat hidrolik, yang umumnya mengandung satu atau lebih bentuk kalsium sebagai bahan tambahan yang digiling bersamasama dengan bahan utamanya.

\subsubsection{Pasir (Ps)}

Penggunaan pasir sebagai agregat halus untuk membuat campuran batako harus dipilih dengan kualifikasi yang baik, ciri agregat halus yang baik adalah sesuai dengan persyaratan yang ada dalam PBI 1971 pasal 1-6.

\subsubsection{Sludge (Slg)}

Sludge mengandung bahan yang berserat tinggi serta sisa-sisa bahan pengisi termasuk logam, adanya kandungan logam tersebut memungkinkan limbah padat tersebut dapat berfungsi sebagai agregat (Ir. Didik Bambang Supriyadi, MT, 2006).

\subsubsection{Air}

Air diperlukan pada pembuatan beton untuk memicu proses kimiawi semen, membasahi agregat dan memberikan kemudahan dalam pekerjaan beton. Air yang digunakan sebagai campuran beton adalah yang tidak mengandung senyawa - senyawa berbahaya, garam, minyak, gula, atau bahan kimia lainnya.

\section{METODOLOGI}

Pengujian material berupa uji kimia dan uji fisik. Uji kimia dilakukan terhadap PC, dan Sludge sedangkan uj $\mathrm{i}$ fisik dilakukan terhadap PC, pasir, dan Sludge. Uji kimia dan fisik semen sesuai syarat SNI 15-204994, kehalusan, waktu pengikatan dan kuat tekan dilakukan di PT. Semen Gresik. Sedangkan uji fisik semen yang meliputi berat jenis, dan berat volume dilakukan di Laboratorium Diploma 3 Teknik Sipil ITS. Uji kimia Sludge dilakukan oleh PT. Adiprima Suraprinta di PT. Envilab Indonesia. Uji fisika pasir dan sludge yang meliputi berat jenis, kehalusan, air resapan, kadar zat organik, kadar lumpur, dan berat volume dilakukan di Laboratorium Diploma 3 Teknik Sipil ITS.

Sebelum melakukan pembuatan benda uji, dilakukan penentuan berat dari masing masing komposisi campuran. Komposisi campuran yang digunakan dalam penelitian ini dapat dilihat pada tabel 3.1 dihalaman berikut :

Tabel 3.1 Kode komposisi masing-masing campuran dengan perbandingan berat $\mathrm{kg}$

\begin{tabular}{|c|c|c|c|c|c|}
\hline Komposisi & PC & Pasir & Sludge & Fas & $\begin{array}{c}\% \\
\text { Sludge }\end{array}$ \\
\hline 1 & 1 & 5 & 0 & 0,4 & 0 \\
\hline 2 & 1 & 3,75 & 1,25 & 0,4 & 25 \\
\hline 3 & 1 & 6 & 0 & 0,4 & 0 \\
\hline 4 & 1 & 4,5 & 1,5 & 0,4 & 25 \\
\hline 5 & 1 & 5 & 0 & 0,5 & 0 \\
\hline 6 & 1 & 3,75 & 1,25 & 0,5 & 25 \\
\hline 7 & 1 & 6 & 0 & 0,5 & 0 \\
\hline 8 & 1 & 4,5 & 1,5 & 0,5 & 25 \\
\hline
\end{tabular}




\section{Diagram Alur Penelitian}
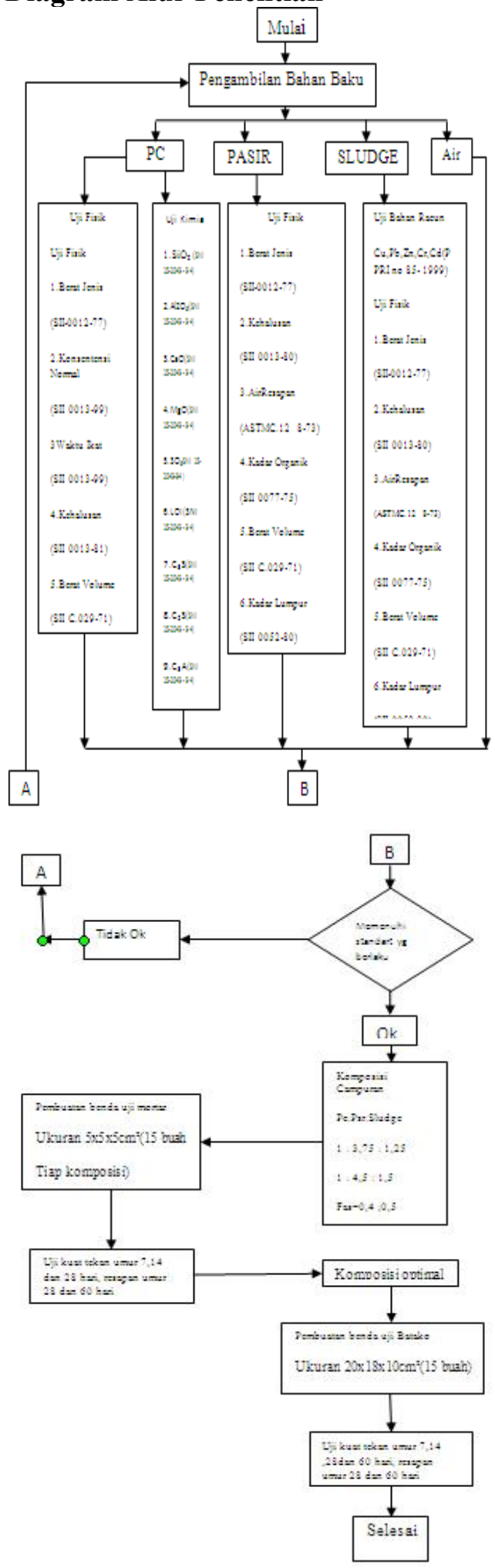

4. HASIL PENILITIAN

4.1. Hasil Uji Bahan Dasar.

4.1.1 Semen Portland (Pc)

Berdasarkan hasil penelitian, maka kandungan kimia semen portland memenuhi syarat SNI 15 - 2049 - 04 yang ada pada Iampiran 1. Untuk uji fisik berat jenis dan berat volume tidak ada standartnya, sedangkan konsistensi normal nilainya 67,5cc memenuhi SII 0013-81 dimana standartnya $60-70 \mathrm{cc}$. Sehingga semen Portland type I dari PT. Semen Gresik (Pesero) dapat dipakai sebagai bahan perekat pada campuran beton.

\subsubsection{Pasir (Ps)}

Uji fisik pasir yang dilakukan di Laboratorium Uji Beton D3 Teknik Sipil, ITS didapatkan hasil sebagai berikut :

a. Berat jenis pasir 2,55 , air resapan $3,86 \%$ berat isi lepas $1,50 \mathrm{gr} / \mathrm{cc}$ dan berat isi dirojok 1,62 gr/ cc tidak ada syarat dalam SII.

b. Kadar lumpur yang nilainya $1.17 \%$ memenuhi syarat SII 0052-80 dimana maksimum kadar lumpur adalah $5 \%$

c. Kadar organik dengan warna kuning bening memenuhi syarat dari SII 0052-80.

d. Kehalusan 3,788 yang memenuhi standart SII 0052-80 dimana syaratnya adalah 1.50 s/d 3.80

Dari uraian diatas, dapat disimpulkan bahwa pasir jenis ini dapat dipakai sebagai campuran beton.

\subsubsection{Sludge (Slg)}

Berdasarkan hasil uji kimia limbah sludge kertas PT. Adiprima Suraprinta memenuhi batas maksimal kandungan zat berbahaya pada limbah sesuai dengan PPRI. No 85 Tahun1999 tercantum pada tabel 4.4. Sehingga limbah sludge kertas dapat dipakai sebagai bahan tambahan campuran beton.

Dari hasil uji fisik yang tercantum pada tabel 4, 6 didapat berat jenis Sludge kondisi kering 1,65 dan berat volume $0,50 \mathrm{gr} / \mathrm{cc}$ tidak ada standartnya.

\subsubsection{Air Air yang digunakan berasal dari PDAM, sesuai PB-1989 pasal 3.4.1 untuk pembuatan dan perawatan beton adalah tidak boleh mengandung minyak, asam, alkali, garam-garam, bahan-bahan organis atau bahan-bahan lain yang merusak beton}


atau tulangan. Sebaiknya dipakai air tawar yang dapat diminum.

\subsection{Analisa Hasil Mortar}

\subsubsection{Hasil Analisa Kuat Tekan Mortar dengan Umur.}

Pada hasil analisa uji kuat tekan mortar dapat dilihat pada :

> Pada campuran 1 tanpa menggunakan sludge mempunyai kuat tekan umur 7 hari sebesar $26,67 \mathrm{~kg} / \mathrm{cm}^{2}$ dan nilai kuat tekan umur 14 hari sebesar $30,67 \mathrm{~kg} / \mathrm{cm}^{2}$ sehingga mengalami penambahan kuat tekan sebesar $14,9 \%$ sedangkan kuat tekan pada umur 28 hari sebesar $34,67 \mathrm{~kg} / \mathrm{cm}^{2}$ mengalami kenaikan kuat tekan sebesar 13,04\% dibandingkan umur 14 hari. Untuk penambahan $25 \%$ sludge yaitu komposisi 2 memiliki kuat tekan umur 7, 14 dan 28 hari, masing-masing $14,67 \mathrm{~kg} / \mathrm{cm}^{2}, 18,67 \mathrm{~kg} / \mathrm{cm}^{2}$ dan 29,33 $\mathrm{kg} / \mathrm{cm}^{2}$. Terjadi kenaikan kuat tekan $27,26 \%$ pada umur 14 hari dibanding dengan 7 hari, sedangkan penambahan penambahan kuat tekan umur 28 hari adalah $57,1 \%$ dibanding umur 14 hari. Untuk komposisi campuran tanpa sludge dengan komposisi campuran yang menggunakan $25 \%$ sludge pada umur 7, 14 dan 28 hari, terjadi penurunan kuat tekan masing-masing sebesar $81,79 \% 64,27 \%$ dan $18,20 \%$

Dapat dikatakan untuk komposisi 1:5 dengan fas 0,4 pada umur 28 hari kuat tekannya menurun sebesar $18,20 \%$

$>$ Pada campuran 3 tanpa menggunakan sludge mempunyai kuat tekan umur 7 hari sebesar $24,00 \mathrm{~kg} / \mathrm{cm}^{2}$ dan nilai kuat tekan umur 14 hari sebesar $30,67 \mathrm{~kg} / \mathrm{cm}^{2}$ sehingga mengalami penambahan kuat tekan sebesar $21,74 \%$ sedangkan kuat tekan pada umur 28 hari sebesar $33,33 \mathrm{~kg} / \mathrm{cm}^{2}$ mengalami kenaikan kuat tekan sebesar 8,67\% dibandingkan umur 14 hari. Untuk penambahan $25 \%$ sludge yaitu komposisi $\mathbf{4}$ memiliki kuat tekan umur 7, 14 dan 28 hari, masing-masing $13,33 \mathrm{~kg} / \mathrm{cm}^{2}, 22,67 \mathrm{~kg} / \mathrm{cm}^{2}$ dan 28,00 $\mathrm{kg} / \mathrm{cm}^{2}$. Terjadi kenaikan kuat tekan $70,06 \%$ pada umur 14 hari dibanding dengan 7 hari, sedangkan penambahan penambahan kuat tekan umur 28 hari adalah 23,51\% dibanding umur 14 hari. Untuk komposisi campuran tanpa sludge dengan komposisi campuran yang menggunakan $25 \%$ sludge pada umur 7, 14 dan 28 hari, terjadi penurunan kuat tekan masing-masing sebesar $80,04 \% 35,28 \%$ dan $19,04 \%$

Dapat dikatakan untuk komposisi 1:5 dengan fas 0,4 pada umur 28 hari kuat tekannya menurun sebesar $19,04 \%$

Pada campuran 5 tanpa menggunakan sludge mempunyai kuat tekan umur 7 hari sebesar $26,67 \mathrm{~kg} / \mathrm{cm}^{2}$ dan nilai kuat tekan umur 14 hari sebesar $32,00 \mathrm{~kg} / \mathrm{cm}^{2}$ sehingga mengalami penambahan kuat tekan sebesar $19,98 \%$ sedangkan kuat tekan pada umur 28 hari sebesar $33,33 \mathrm{~kg} / \mathrm{cm}^{2}$ mengalami kenaikan kuat tekan sebesar 4,2\% dibandingkan umur 14 hari. Untuk penambahan $25 \%$ sludge yaitu komposisi 6 memiliki kuat tekan umur 7, 14 dan 28 hari, masing-masing $12,00 \mathrm{~kg} / \mathrm{cm}^{2}, 18,67 \mathrm{~kg} / \mathrm{cm}^{2}$ dan 25,33 $\mathrm{kg} / \mathrm{cm}^{2}$. Terjadi kenaikan kuat tekan $55,58 \%$ pada umur 14 hari dibanding dengan 7 hari, sedangkan penambahan penambahan kuat tekan umur 28 hari adalah 35,67\% dibanding umur 14 hari. Untuk komposisi campuran tanpa sludge dengan komposisi campuran yang menggunakan $25 \%$ sludge pada umur 7, 14 dan 28 hari, terjadi penurunan kuat tekan masing-masing sebesar $122,25 \% 71,39 \%$ dan $31,58 \%$

Dapat dikatakan untuk komposisi 1:5 dengan fas 0,4 pada umur 28 hari kuat tekannya menurun sebesar $31,58 \%$

Pada campuran 7 tanpa menggunakan sludge mempunyai kuat tekan umur 7 
hari sebesar $22,67 \mathrm{~kg} / \mathrm{cm}^{2}$ dan nilai kuat tekan umur 14 hari sebesar $30,67 \mathrm{~kg} / \mathrm{cm}^{2}$ sehingga mengalami penambahan kuat tekan sebesar $35,28 \%$ sedangkan kuat tekan pada umur 28 hari sebesar $32,00 \mathrm{~kg} / \mathrm{cm}^{2}$ mengalami kenaikan kuat tekan sebesar 4,33\% dibandingkan umur 14 hari. Untuk penambahan $25 \%$ sludge yaitu komposisi 8 memiliki kuat tekan umur 7, 14 dan 28 hari, masing-masing $10,67 \mathrm{~kg} / \mathrm{cm}^{2}, 22,67 \mathrm{~kg} / \mathrm{cm}^{2}$ dan 26,67 $\mathrm{kg} / \mathrm{cm}^{2}$. Terjadi kenaikan kuat tekan $112,46 \%$ pada umur 14 hari dibanding dengan 7 hari, sedangkan penambahan penambahan kuat tekan umur 28 hari adalah $17,64 \%$ dibanding umur 14 hari. Untuk komposisi campuran tanpa sludge dengan komposisi campuran yang menggunakan $25 \%$ sludge pada umur 7, 14 dan 28 hari, terjadi penurunan kuat tekan masing-masing sebesar $112,46 \%, 35,28 \%$ dan $19,98 \%$

Dapat disimpulkan untuk komposisi 1:5 dengan fas 0,4 pada umur 28 hari kuat tekannya menurun sebesar $19,98 \%$

Dari data kuat tekan masing- masing campuran diatas disimpulkan pada komposisi campuran $1 \mathrm{Pc}: 5 \mathrm{Psr}$ dengan fas 0,5 yaitu komposisi 6 nilai kuat tekan $25,33 \mathrm{~kg} / \mathrm{cm}^{2}$ sudah diatas kuat tekan HB20 yang memiliki nilai kuat tekan $20 \mathrm{~kg} / \mathrm{cm} 2$. Dimana dari data tersebut akan dibuat sebagai acuan dalam pembuatan batako.

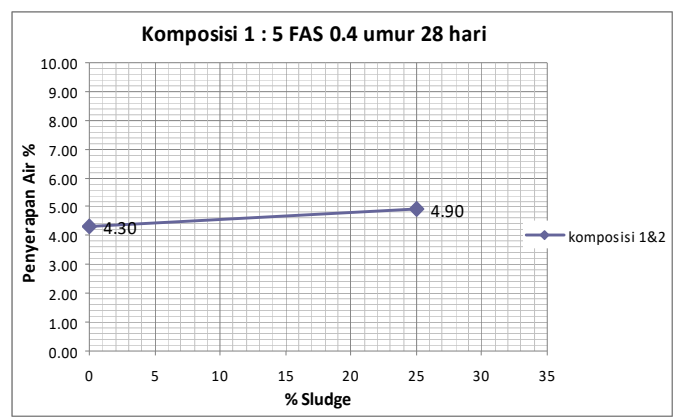

Grafik 4.1 Hubungan \%sludge dengan \% resapan

\subsection{Hasil Analisa Penyerapan Mortar dengan \% Sludge.}

Pada hasil analisa uji penyerapan mortar dapat dilihat pada:

$>$ Memperhatikan resapan pada umur 28 hari komposisi 1 dengan $0 \%$ sludge mempunyai nilai resapan $4,3 \%$ sedang bila ditambah $25 \%$ sludge yaitu komposisi 2 resapannya 4,9\% sehingga nilai resapan naik $13,95 \%$ Pada umur 60 hari grafik 4.9 dan tabel 4.8 komposisi 1 resapannya 4,4\% sedang komposisi 2 resapannya 5,0\% sehingga nilai resapan naik $13,63 \%$

Bahwa dengan makin bertambahnya umur maka resapan juga bertambah yaitu untuk komposisi 1 sebesar 2,32\% dan komposisi 2 sebesar 2,04\%

$>$ Memperhatikan resapan pada umur 28 hari komposisi 3 dengan $0 \%$ sludge mempunyai nilai resapan 4,5\% sedang bila ditambah $25 \%$ sludge yaitu komposisi 4 resapannya 5,1\% sehingga nilai resapan naik $13,33 \%$ Pada umur 60 hari grafik 4.10 dan tabel 4.8 komposisi 3 resapannya $4,7 \%$ sedang komposisi 4 resapannya 5,2\% sehingga nilai resapan naik $10,63 \%$

Bahwa dengan makin bertambahnya umur maka resapan juga bertambah yaitu untuk komposisi 3 sebesar 4,44\% dan komposisi 4 sebesar 1,96\%

> Memperhatikan resapan pada umur 28 hari komposisi $\mathbf{5}$ dengan $0 \%$ sludge mempunyai nilai resapan $6,0 \%$ sedang bila ditambah $25 \%$ sludge yaitu komposisi 6 resapannya 6,6\% sehingga nilai resapan naik $10 \%$ Pada umur 60 hari grafik 4.11 dan tabel 4.8 komposisi 5 resapannya $6,3 \%$ sedang komposisi 6 resapannya $6,7 \%$ sehingga nilai resapan naik $6,34 \%$

Bahwa dengan makin bertambahnya umur maka resapan juga bertambah yaitu untuk komposisi $\mathbf{5}$ sebesar 5\% dan komposisi 6 sebesar 1,51\%

$>$ Memperhatikan resapan pada umur 28 hari komposisi 7 dengan 0\% sludge 
mempunyai nilai resapan $7,1 \%$ sedang bila ditambah $25 \%$ sludge yaitu komposisi 8 resapannya 7,9\% sehingga nilai resapan naik $11,26 \%$ Pada umur 60 hari grafik 4.12 dan tabel 4.8 komposisi 7 resapannya $7,3 \%$ sedang komposisi 8 resapannya 8,0\% sehingga nilai resapan naik $9,59 \%$

Bahwa dengan makin bertambahnya umur maka resapan juga bertambah yaitu untuk komposisi 7 sebesar 2,82\% dan komposisi 8 sebesar 1,27\%

Dapat disimpulkan dengan bertambahnya umur, air resapan makin bertambah pula sekitar $1,5 \%-5 \%$

\subsection{Hasil Analisa Perbandingan Berat Kering Mortar dengan Tiap-Tiap Komposisi.}

Pada hasil analisa perbandingan berat kering mortar dapat dilihat pada:

> Memperhatikan besar berat kering mortar terhadap komposisi bahwa pada komposisi 1 memiliki berat kering sebesar 217 gram bila ditambah 25\% sludge menjadi komposisi $\mathbf{2}$ yang memiliki berat kering sebesar 209,57 gram sehingga beratnya berkurang 3,55\% dibanding komposisi $\mathbf{1}$.

Bahwa dengan penambahan 25\% sludge menyebabkan berat kering mortar akan berkurang 3,55\%

> Memperhatikan besar berat kering mortar terhadap komposisi bahwa pada komposisi $\mathbf{3}$ memiliki berat kering sebesar 219, 33 gram bila ditambah $25 \%$ sludge menjadi komposisi $\mathbf{4}$ yang memiliki berat kering sebesar 211,03 gram sehingga beratnya berkurang 3,93\% dibanding komposisi 4.

Bahwa dengan penambahan 25\% sludge menyebabkan berat kering mortar akan berkurang 3,93\%

> Memperhatikan besar berat kering mortar terhadap komposisi bahwa pada komposisi $\mathbf{5}$ memiliki berat kering sebesar 217,6 gram bila ditambah 25\% sludge menjadi komposisi $\mathbf{6}$ yang memiliki berat kering sebesar 209,87 gram sehingga beratnya berkurang 3,68\% dibanding komposisi 5 .

Bahwa dengan penambahan $25 \%$ sludge menyebabkan berat kering mortar akan berkurang 3,68\%

$>$ Memperhatikan besar berat kering mortar terhadap komposisi bahwa pada komposisi $\mathbf{7}$ memiliki berat kering sebesar 220,07 gram bila ditambah 25\% sludge menjadi komposisi 8 yang memiliki berat kering sebesar 211,4 gram sehingga beratnya berkurang 4,10\% dibanding komposisi 7.

Bahwa dengan penambahan $25 \%$ sludge menyebabkan berat kering mortar akan berkurang $4,10 \%$

Dapat disimpulkan bahwa dengan penambahan $25 \%$ sludge, berat mortar akan berkurang sekitar 3,5\%4,10\% Dan dari data tersebut komposisi 6 perbandingan campuran 1Pc:3,75Psr:1,25Sludge dengan fas 0,5 dijadikan sebagai acuan dalam pembuatan batako karena mempunyai berat jenis lebih kecil yaitu sebesar 1,67 dibanding dengan komposisi lain yang mempunyai berat jenis antara 1,68 -1,76.

\subsection{Analisa Hasil Batako}

Bahwa memperhatikan analisa kuat tekan, resapan dan berat kering mortar memilih komposisi 6 dengan perbandingan campuran 1:5 dengan fas 0,5 yang optimal karena mempunyai kuat tekan yang diatas HB20.

\subsubsection{Hasil Analisa Kuat Tekan Batako} dengan Umur.

Berdasarkan SII.0285-1980 uji kuat tekan paling tidak sama dengan kuat tekan HB20. Dibawah berikuthasil analisa uji kuat tekan batako dapat dilinat:

$>$ Pada campuran 6 dengan menggunakan $25 \%$ sludge pengganti pasir mempunyai kuat tekan umur 7 hari sebesar $10,33 \mathrm{~kg} / \mathrm{cm}^{2}$ dan nilai kuat tekan umur 14 hari sebesar $15,67 / \mathrm{cm}^{2}$ sehingga 
mengalami penambahan kuat tekan sebesar $51,69 \%$, kuat tekan pada umur 28 hari sebesar $34,67 \mathrm{~kg} / \mathrm{cm}^{2}$ mengalami kenaikan kuat tekan sebesar $42,50 \%$ dibandingkan umur 14 hari. Sedangkan kuat tekan pada umur 60 hari sebesar $23,67 \mathrm{~kg} / \mathrm{cm}^{2}$ mengalami kenaikan kuat tekan sebesar $6 \%$ dibandingkan umur 28 hari.

Dapat dikatakan nilai kuat tekan batako umur 28 dan 60 hari memenuhi SII.02851980 yaitu diatas HB20 yang kuat tekannya $20 \mathrm{~kg} / \mathrm{cm}^{2}$

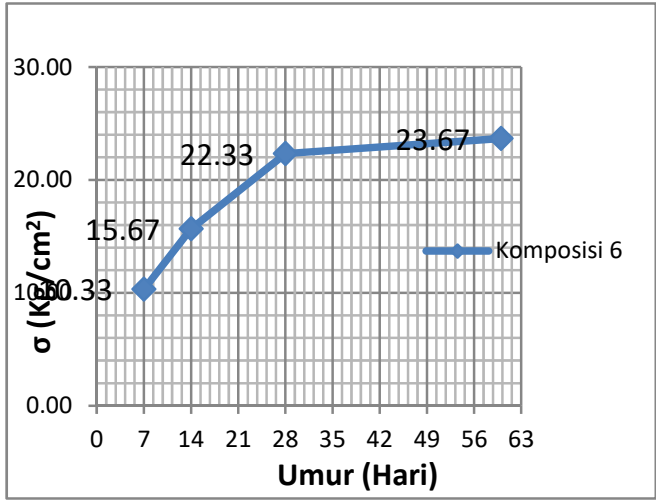

Grafik 4.2 Hubungan umur batako dengan kuat tekan

\subsubsection{Hasil Analisa Penyerapan Potongan Batako Ukuran $10 \times 10 \times 10 \mathrm{~cm}^{3}$ dengan Umur.}

Hasil analisa uji penyerapan potongan batako dapat dilihat:

$>$ Pada umur 28 hari komposisi 6 dengan $25 \%$ sludge mempunyai nilai resapan $8,2 \%$ sedang pada umur 60 hari grafik 4.18 dan tabel 4.12 resapannya $8,4 \%$ sehingga nilai resapan mengalami kenaikan sebesar 2,4\%

Dapat dikatakan nilai resapan potongan batako yang mewakili batako utuh umur 28 dan 60 hari memenuhi SII.0285-1980 karena syaratnya tidak terbatas.

\subsubsection{Hasil Analisa Perbandingan berat kering batako dengan umur batako.}

Pada hasil analisa perbandingan berat kering batako dengan umur dapat dilihat :

> Pada campuran 8 dengan menggunakan $25 \%$ sludge pengganti pasir mempunyai berat kering umur 7 hari sebesar 8345,6 gr dan berat kering umur 14 hari sebesar 8335,1 gr sehingga mengalami penuruan berat kering sebesar $0,13 \%$ berat kering pada umur 28 hari sebesar 8320,9 gr mengalami penurunan berat kering sebesar $0,17 \%$ dibandingkan umur 14 hari sedangkan berat kering pada umur 60 hari sebesar 8305, $3 \mathrm{gr}$ mengalami penurunan berat kering sebesar 0,19\% dibandingkan umur 28 hari.

Dapat dikatakan besar berat kering batako memenuhi karena tidak ada standartnya. Dimana beratnya dibandingkan yang ada dipasaran lebih ringan yaitu berat batako yang ada di pasaran rata-rata sebesar 8875,7 gram sedangkan batako sendiri rata-rata sebesar 8345, 6 gram.

\section{KESIMPULAN}

1. Bahwa sludge dapat digunakan untuk pembuatan batako.Dimana sludge pengganti pasir yang ditambahkan sebesar $25 \%$ pada penelitian ini.

2. Bahwa kuat tekan yang dipakai untuk acuan pembuatan batako yaitu pada komposisi 6 dengan perbandingan campuran 1Pc:3,75Psr:1,25 sludge dan fas 0,5 yang kuat tekannya $25,33 \mathrm{~kg} / \mathrm{cm} 2$ karena sudah melampaui kuat tekan HB20.

3. Nilai kuat tekan batako umur 28 dan 60 hari sebesar $22,33 \mathrm{~kg} / \mathrm{cm}^{2}$ dan $23,67 \mathrm{~kg} / \mathrm{cm}^{2}$ memenuhi SII.0285-1980 yaitu diatas HB20 yang kuat tekannya $20 \mathrm{~kg} / \mathrm{cm} 2$

4. Dapat disimpulkan dengan bertambahnya umur, resapan makin bertambah pula itu ditunjukkan dengan 
nilai resapan batako umur 28 dan 60 hari sebesar 8,2\% dan 8,4\% memenuhi SII. 0285-1980 karena yang diuji resapan adalah potongan batako yang mewakili batako utuh dimana syaratnya tidak terbatas.

5. Berat kering batako memenuhi karena tidak ada standartnya pada SII. Dimana beratnya dibandingkan yang ada dipasaran lebih ringan yaitu berat batako yang dipasaran rata-rata sebesar 8875,7 gram sedangkan batako dengan penambahan $25 \%$ sludge rata-rata sebesar 8345,6gram. Sehingga lebih ringan 6,35\%dibanding batako dipasaran

6. Berdasarkan SII.0285-1980, hasil kuat tekan pada penelitian dapat diklasifikasikan pada mutu HB 20, yang digunakan untuk rumah sederhana.

\section{DAFTAR PUSTAKA}

Acuan yang dipakai untuk penulisan artikel ini antara lain:

[1]. Bambang Supriyadi, Didik.2006." Pemanfaatan Limbah Padat (Sludge) Pabrik Kertas Sebagai Bata Beton (Batako) Untuk Mereduksi Kuantitas Limbah" Laporan Penelitian. ITS. Surabaya.

[2]. Das M, Braja.1991. Terjemahan Endah Noor, Mochtar." Mekanika Tanah(Prinsipprinsip Rekayasa Geoteknis) Jilid1. Erlangga.

[3]. Fitria, 2005. "Kandungan logam berat $(\mathrm{Pb}, \mathrm{Cu}, \mathrm{Hg})$ dan pemanfaatan lumpur IPAL(industri Pengolahan air limbah) pabrik kertas PT Adiprima Suraprinta sebagai paving block". Skripsi. Fakultas Kesehatan Masyarakat UNAIR. Surabaya.

[4]. Mutu dan Cara Uji Bata Beton Berongga, Sll.0285-1980.

[5]. Mutu dan Cara uj $\mathrm{i}$ Pasir standart, Sll. 0287-80

[6]. Peraturan Beton Bertulang Indonesia, 1971. Direktorat J enderal Cipta Karya.

[7]. Pedoman Beton, 1989. Badan Penelitian dan Pengembangan PU. 